\title{
Iron Bioavailability Studied in Infants: The Influence of Phytic Acid and Ascorbic Acid in Infant Formulas Based on Soy Isolate
}

\author{
LENA DAVIDSSON, PILAR GALAN, PETER KASTENMAYER, \\ FRANÇOISE CHEROUVRIER, MARCEL-A. JUILLERAT, SERGE HERCBERG, AND \\ RICHARD F. HURRELL \\ Nestlé Research Centre, Vers-chez-les-Blanc, CH-1000 Lausanne 26, Switzerland [L.D., P.K., \\ M.-A.J., R.F.H.l, and Centre de Recherche sur les Anémies Nutritionnelles, Conservatoire \\ National des Arts et Métiers, F-75003 Paris, France [P.G., F.C., S.H.]
}

\section{ABSTRACT}

The influence of phytic acid and ascorbic acid content of soy formula on iron $(\mathrm{Fe})$ bioavailability was investigated in infants by analysis of the incorporation of stable isotopes of $\mathrm{Fe}$ into red blood cells $14 \mathrm{~d}$ after administration using a double stable isotope technique. Paired comparisons were made with each infant acting as his or her own control. The geometric mean fractional $\mathrm{Fe}$ incorporation into red blood cells increased from 5.5 to $6.8 \%(p<0.05)$ when soy formula with the native content of phytic acid was compared with a $83 \%$ dephytinized formula. A more pronounced effect was shown with soy formula containing no phytic acid; the mean fractional $\mathrm{Fe}$ incorporation increased from 3.9 (native phytic acid) to $8.7 \%$ (zero phytic acid; $p<$
0.001). A significant $(p<0.01)$ effect was also demonstrated when the $\mathrm{Fe}$ :ascorbic acid molar ratio in the native phytate-containing formula was increased from 1:2.1 to 1:4.2; mean fractional $\mathrm{Fe}$ incorporation increased from 5.9 to $9.6 \%$. These results demonstrate that the Fe bioavailability from soy-based infant formulas can be similarly increased by either removing phytic acid or increasing the ascorbic acid content. (Pediatr Res 36: 816-822, 1994)

Fe, iron

Abbreviations

$\mathbf{C V}$, coefficient of variation
Infant formulas based on soy isolate are frequently used as an alternative to products based on cow's milk when non-breast-fed infants are allergic or have intolerances to lactose or to the proteins present in cow's milk. Soy formulas are generally well accepted and have not been associated with any problems in the infants' nutritional status, although the bioavailability of nutrients, especially minerals, has been reported to be lower than that from milk-based products. For example, studies in adults have demonstrated that $\mathrm{Fe}$ absorption is significantly lower from soy formula than from cow's milk formula $(1,2)$. Zinc absorption is also lower from soy formula than from both human milk and cow's milk formulas (3), and children recovering from malnutrition have been shown to gain less weight when fed soy formula (4). In addition, lower bone mineral content has been reported in infants consuming soy formula (5), although this was later related to the poor suspendibility of the added minerals in the formulas (6). This lower bio-

Received November 30, 1993; accepted May 31, 1994.

Correspondence and reprint requests: Lena Davidsson, Nestlé Research Center, P.O. Box 44, CH-1000 Lausanne 26, Switzerland. availability of minerals in soy products has raised questions concerning the mineral status of infants fed soy-based products over long periods of time, and strategies to ensure adequate mineral nutrition from soy-based products are a major concern of the infant food manufacturers.

An important factor contributing to the low mineral absorption from soy products is the relatively high content of phytic acid (inositol hexaphosphate) present in soy beans. Phytic acid is a strong metal chelator present in many legumes, vegetables, and cereals. The negative effect of phytic acid on Fe absorption has been demonstrated in adults (7-9) as a dose-dependent effect $(7,10)$. Techniques are now available to remove phytic acid from soy isolate by enzymatic treatment with phytase (EC 3.1.3.8). By this technique, the content of phytic acid in soy isolate can be reduced to virtually zero. The complete degradation of phytic acid in soy isolate using phytase has been demonstrated to increase absorption of Fe significantly in adults (8), when the dephytinized isolate was consumed as the sole protein source in a liquid test meal.

Fe bioavailability from foods can also be increased by the addition of ascorbic acid. The positive effect of ascor- 
bic acid on $\mathrm{Fe}$ absorption has been demonstrated to counteract the inhibition of phytic acid $(7,10)$, and an enhancing effect on $\mathrm{Fe}$ absorption from soy formula has been shown in studies of adult women $(1,2)$. However, no studies on the effect of ascorbic acid on Fe bioavailability from soy formula in infants have been reported.

In the present study, we evaluated the effect of phytic acid and ascorbic acid on fractional Fe incorporation into red blood cells in healthy infants fed soy formula by using a recently developed double stable isotope technique. This methodology enabled the simultaneous measurement of fractional $\mathrm{Fe}$ incorporation into red blood cells from two test meals, one labeled with ${ }^{57} \mathrm{Fe}$ and one with ${ }^{58} \mathrm{Fe}$ (11). Isotopic enrichment of $\mathrm{Fe}$ in red blood cells was measured by thermal ionization mass spectrometry $14 \mathrm{~d}$ after administration, and incorporation into red blood cells was calculated based on information of the isotope ratio shifts, total circulating $\mathrm{Fe}$ and intake of each isotope. Furthermore, $90 \%$ of the initially absorbed $\mathrm{Fe}$ was assumed to be incorporated into red blood cells (12). Paired comparisons were made between soy formula containing the native content of phytic acid with formulas in which the phytic acid has been reduced to 83 or $100 \%$. In addition, we compared Fe bioavailability from a soy formula containing the native phytic acid content at two concentrations of ascorbic acid. The normal level (624 $\mu \mathrm{mol} / \mathrm{L} ; 110 \mathrm{mg} / \mathrm{L}$ ) was compared with twice this amount $(1249 \mu \mathrm{mol} / \mathrm{L} ; 220 \mathrm{mg} / \mathrm{L})$.

\section{METHODS}

Subjects. Healthy, formula-fed term infants were recruited at a children's health center in central Paris. Ten infants participated in each of the three studies. Parents were fully informed about the aims and procedures of the study both orally and in writing, and informed consent was obtained from at least one parent of each infant. All infants were apparently healthy and living at home. The mean age at the time of the studies was 21 wk (range 13-30 wk). All children were fed an Fe-fortified commercial soy formula (Alsoy, Nestlé, Vevey, Switzerland) for at least 2 wk before the study. The prefeeding period was included in the protocol to make sure that the infants accepted soy formula before being enrolled in the study. The study was approved by the ethical committee of Paris-Cochin.

Test meals. Four soy formulas (A-D) were manufactured specifically for the studies at Alpura Koreco, Konolfingen, Switzerland. All products were produced according to the specification for a commercial soy formula (Nestlé S.A., Vevey, Switzerland) but without added Fe, zinc, or ascorbic acid. Soy isolate (Protein Technologies International, St. Louis, MO) was used as the protein source; isolate EdiproA was used for products A and B, and isolate Supro 1611 was used for products $C$ and $D$. The products were manufactured on two separate occasions over a period of approximately 1 y. Two parallel products (A and B, C and D) were made during each manufacturing, one containing the native phytic acid content ( $\mathrm{A}$ and $\mathrm{C}$ ) and the identical product being dephytinized by the addition of phytase (EC 3.1.3.8) to the soy isolate (product $\mathrm{B}, 83 \%$ dephytinized; product D, 100\% dephytinized). The enzyme (Finase S40) was purchased from Alko Ltd. (Helsinki, Finland). It was derived from Aspergillus niger and contained 40 phytase units/L. Products A and B (used in studies 1 and 3 ) were produced as spray-dried powders, whereas products C and D (used in study 2) were made as "ready-tofeed" liquid formulas for practical reasons. The liquid formulas were aseptically transferred into cans; the dry powders were transferred into cans and gassed with nitrogen. All products were subject to the same control system as commercial products, including microbiologic tests and analysis of the nutritional composition, before being released from the factory.

Stable isotopes. Enriched stable isotopes of ${ }^{58} \mathrm{Fe}$ $\left[59.55 \%{ }^{58} \mathrm{Fe}\right.$ (oxide; studies 1 and 2 ) and $93.21 \%{ }^{58} \mathrm{Fe}$ (metal; study 3)] and ${ }^{57} \mathrm{Fe}-$ metal $\left(95.30 \%{ }^{57} \mathrm{Fe}\right.$, study 1 ; $95.10 \%{ }^{57} \mathrm{Fe}$, study 2 ; and $95.27 \%{ }^{57} \mathrm{Fe}$, study 3) were purchased from Medgenix Diagnostics, Ratingen, Germany. The $\mathrm{Fe}$ compounds enriched with ${ }^{57} \mathrm{Fe}$ and ${ }^{58} \mathrm{Fe}$ were converted into $\mathrm{FeSO}_{4}$ by dissolving the $\mathrm{Fe}$ metal or oxide in $7 \mathrm{M} \mathrm{HNO}_{3}$ followed by the addition of $0.5 \mathrm{M}$ $\mathrm{H}_{2} \mathrm{SO}_{4}$. The solutions were then heated to dryness at $120^{\circ} \mathrm{C}$. After additional heating at $230^{\circ} \mathrm{C}$ and $500^{\circ} \mathrm{C}$, the white powder was dissolved in $0.5 \mathrm{M} \mathrm{H}_{2} \mathrm{SO}_{4}(1 \mathrm{~mL} / 10 \mathrm{mg}$ $\mathrm{Fe})$. The solutions were filtered through a Teflon filter (Millex-FH13, Millipore AG, Zürich, Switzerland). The $\mathrm{Fe}(\mathrm{III})$ was then reduced to $\mathrm{Fe}$ (II) by the addition of ascorbic acid (Merck, Darmstadt, Germany) at a molar ratio of $1: 1$ followed by dilution to give an Fe concentration of approximately $1 \mathrm{mg} / \mathrm{mL}$. All isotope solutions were made immediately before the studies to avoid potential problems with oxidized Fe solutions. Isotope solutions were poured into 5-mL Reacti vials (Pierce, Rockford, IL), purged with nitrogen, and kept refrigerated until used. During preparations of stable isotope labels, as well as for all analytical work, only acids purified by subboiling distillation and ultrapure water $(18 \mathrm{M} \Omega$ ) from a Millipore system (Millipore AG) were used. Other chemicals were of analytical grade purity, except the $\mathrm{H}_{2} \mathrm{O}_{2}$ solution, which was superpure. To minimize contamination through vessel materials, only acid-washed quartz, Teflon, and polyethylene containers were used.

Each child received a total ${ }^{57} \mathrm{Fe}$ dose of $81 \mu \mathrm{mol}(4.61$ mg; study 1), $82 \mu \mathrm{mol}$ (4.66 mg; study 2), or $84 \mu \mathrm{mol}(4.76$ mg; study 3$)$; the amount of ${ }^{58} \mathrm{Fe}$ given was $20 \mu \mathrm{mol}(1.18$ mg; study 1), $21 \mu \mathrm{mol}$ (1.20 mg; study 2$)$, and $20 \mu \mathrm{mol}$ $(1.18 \mathrm{mg}$; study 3$)$. The total amount of added $\mathrm{Fe}$ was kept constant between ${ }^{57} \mathrm{Fe}$ and ${ }^{58} \mathrm{Fe}$ administrations by addition of $\mathrm{Fe}$ with normal isotopic composition $\left(\mathrm{FeSO}_{4}\right.$ $\times 7 \mathrm{H}_{2} \mathrm{O}$, Merck) to the ${ }^{58} \mathrm{Fe}$ isotope solutions. The doses of isotopes that had to be administered were calculated based on estimates of the circulating $\mathrm{Fe}$ in infants of this age group and on the enrichment of red blood cells needed for analysis of isotope ratios with an external 
precision of $0.5 \%$ for ${ }^{57} \mathrm{Fe} /{ }^{56} \mathrm{Fe}$ and $1.0 \%$ for ${ }^{58} \mathrm{Fe} /{ }^{56} \mathrm{Fe}$ (11). The amount of ${ }^{58} \mathrm{Fe}$ that had to be given was much less than that of ${ }^{57} \mathrm{Fe}$ due to the lower natural abundance of ${ }^{58} \mathrm{Fe}$.

Study design. Three separate studies were made with 10 infants in each study. Study 1 compared the spray-dried product with its native phytic acid (product $\mathrm{A}$ ) with the same product in which the phytic acid had been $83 \%$ degraded (product B); study 2 compared the liquid readyto-feed product with its native phytic acid (product $\mathrm{C}$ ) with the same product in which phytic acid had been $100 \%$ degraded (product D); and study 3 compared the spray-dried product with its native level of phytic acid (product A) at two concentrations of ascorbic acid, 624 and $1249 \mu \mathrm{mol} / \mathrm{L}$ ( 110 and $220 \mathrm{mg} / \mathrm{L}$ ). Within each study, one formula was labeled with ${ }^{57} \mathrm{Fe}$ and the other with ${ }^{58} \mathrm{Fe}$. All infants received four labeled feeds, two feeds containing each isotope. The total quantity of isotope was divided evenly between the two feeds. One labeled feed per day was fed on 4 consecutive d.

Individual servings of formula (28 $\mathrm{g}$ of powdered formula plus $189 \mathrm{~g}$ of ultrapure water (products $\mathrm{A}$ and $\mathrm{B}$ ) or $217 \mathrm{~g}$ ready-to-feed formula (products $\mathrm{C}$ and $\mathrm{D}$ ) were weighed into plastic feeding bottles. Each serving was labeled immediately before administration. Zinc $\left(\mathrm{ZnSO}_{4}\right.$, Merck) and ascorbic acid [L(+) ascorbic acid, Merck] were added at the same time. Zinc was added to a final concentration of $92 \mu \mathrm{mol} / \mathrm{L}(6 \mathrm{mg} / \mathrm{L})$ and ascorbic acid to $624 \mu \mathrm{mol} / \mathrm{L}(110 \mathrm{mg} / \mathrm{L})$ in all formulas except the second meal of experiment 3 , to which $1249 \mu \mathrm{mol} / \mathrm{L}(220 \mathrm{mg} / \mathrm{L})$ ascorbic acid was added. The labeled formula was heated to $40^{\circ} \mathrm{C}$ before being fed to the infants. Within each study, the infants were randomized to start with either of the two test meals, I $\left({ }^{58} \mathrm{Fe}\right)$ or II $\left({ }^{57} \mathrm{Fe}\right)$, followed by administration of formulas in the order I-II-I-II or II-I-II-I. All formulas were administered after an overnight fast in the morning at the health center under close supervision of the investigators. Preweighed feeding bottles and bibs were used during the feedings to quantify the intake of labeled formula. No food or fluid was given for a period of at least $2 \mathrm{~h}$ after completing the intake of the labeled formula. For standardization, the meal after each labeled test meal consisted of a commercial soy formula provided by the investigators. Venous blood samples were drawn on $\mathrm{d} 1$ and 19 for determination of $\mathrm{Fe}$ status indices and the stable isotope composition of whole blood. Body weight was recorded on $\mathrm{d} 1$ and 19.

During study 3 , special care was taken to avoid losses of ascorbic acid during the administration of labeled formula. The vitamin was added after heating the formula to $40^{\circ} \mathrm{C}$ in a water bath, and a "parallel" bottle was prepared for each administration for later analysis of ascorbic acid. The formula in the parallel bottle was identical with the formula fed to the infant, except for the stable isotopes, which were replaced by $\mathrm{FeSO}_{4}$ of normal isotopic composition. The treatment of the parallel bottle was identical with that of the bottle used for administration of labeled formula, i.e. the bottles were heated to the same temperature, left in room temperature during the same period of time, etc. Aliquots representing the volume of formula consumed were removed from the parallel bottle and transferred into a plastic bottle containing meta-phoshoric acid $(100 \mathrm{~g} / \mathrm{L})$ each time the infant consumed the labeled formula. Thus, after completing each administration, a quantity identical with the total intake of labeled formula was removed from the parallel bottle and mixed with the acid. The formula/meta-phosphoric acid mixtures were transferred into plastic bottles (without leaving any headspace), which were sealed, wrapped in aluminum foil, and frozen until analysis of ascorbic acid. Two standards were prepared each day by adding 624 or $1249 \mu \mathrm{mol} / \mathrm{L}$ ascorbic $\mathrm{acid} / \mathrm{L}$ to $217 \mathrm{~g}$ of heated formula, adding the meta-phosphoric acid, and freezing the samples without any further treatment. The final concentration of meta-phosphoric acid was $20 \mathrm{~g} / \mathrm{L}$ in all samples analyzed for ascorbic acid.

Analysis. The contents of $\mathrm{Fe}$ and calcium in the soy formulas were analyzed by atomic absorption spectrometry (model 975, Varian Techtron, Mulgrave, Australia). Duplicate samples of freeze-dried or spray-dried formulas were ashed in silica Ehrlenmeyer flasks in a muffle furnace at $510^{\circ} \mathrm{C}$ for $48 \mathrm{~h}$. Ash was dissolved in concentrated $\mathrm{HCl}$ and diluted to $25 \mathrm{~mL}$ with ultrapure water. $\mathrm{Fe}$ was measured by standard addition technique. Lanthanum oxide was added to the diluted digest to a final concentration of $10 \mathrm{~g} / \mathrm{L}$ before the calcium content was analyzed. Reference materials [wheat flour 1567a (National Institute of Standards, Gaithersburg, MD) and nonfat milk powder 1549 (National Bureau of Standards, Gaithersburg, MD] were analyzed together with the formulas. The analyzed values were found to be within the certified ranges for $\mathrm{Fe}$ and calcium. Dry weight was determined after drying the samples at $105^{\circ} \mathrm{C}$ for $24 \mathrm{~h}$. Nitrogen was analyzed by Kjeldahl technique, and protein was calculated by applying the factor 6.25 to the nitrogen values. Phytic acid was measured by $\mathrm{Ce}\left(\mathrm{SO}_{4}\right)_{2}$ precipitation according to a modification of the method of Makover (13). Ascorbic acid was analyzed in the parallel bottles prepared during study 3 by electrometric titration with 2,6-dichlorophenol indophenol $(14,15)$. The concentration of $\mathrm{Hb}$ was measured on a Coulter Counter S 560 (Coultronics, Margency, France), and serum ferritin was determined by an ELISA (16).

Analysis of isotope ratios. Blood samples drawn on $\mathrm{d} 1$ and 19 were analyzed for their isotopic composition in duplicate. Samples of whole blood ( $\sim 400 \mathrm{mg})$ were mineralized using a microwave digestion system (MDS-81D, CEM Corp., Matthews, $\mathrm{NC}$ ), with concentrated $\mathrm{HNO}_{3}$ and $30 \% \mathrm{H}_{2} \mathrm{O}_{2}$ added during a two-step procedure. The clear digest was evaporated to dryness under filtered nitrogen and dissolved in concentrated $\mathrm{HCl}$ twice before being taken up in $5 \mathrm{M} \mathrm{HCl}$. Fe was separated from matrix elements by anion exchange chromatography, using a modified version of the method by Fasset et al. (17). Econo columns (Bio-Rad Laboratories, Glattburg, Switzerland) with an inner diameter of $7 \mathrm{~mm}$ were filled to 7 
cm with anion exchange resin (type AG1-X8, 200-400 mesh, Cl-form, Bio-Rad Laboratories). The resin was washed with $60 \mathrm{~mL} 2 \mathrm{M} \mathrm{HNO}_{3}$ using an Ismatec IPN 4 peristaltic pump (Ismatec SA, Zürich, Switzerland) before being regenerated to the chloride form with $100 \mathrm{~mL}$ $1 \mathrm{M} \mathrm{HCl}$. The column was washed with $30 \mathrm{~mL}$ of $5 \mathrm{M} \mathrm{HCl}$ after putting the sample on the column. The $\mathrm{Fe}$ was then eluted with $20 \mathrm{~mL}$ of $1 \mathrm{M} \mathrm{HNO}_{3}$. Total $\mathrm{Fe}$ was determined by atomic absorption spectrometry. Samples were evaporated to dryness in Teflon tubes under filtered nitrogen and redissolved in $0.1 \mathrm{M} \mathrm{HNO}_{3}$ to a final Fe concentration of $0.05 \mathrm{M}$. To check for contamination of samples during processing, chemistry blanks were prepared by using an ${ }^{57} \mathrm{Fe}$-enriched spike.

Isotope ratios were measured using a computercontrolled thermal ionization mass spectrometer (model THQ, Finnigan MAT, Bremen, Germany) equipped with a secondary electron multiplier, a 13-sample turret, and a reference pyrometer. Analysis was done with single rhenium filaments, using a silica gel ionization enhancement technique (18). Aluminum was added to further increase the ion yield (19). During analysis, the filaments were heated to $1320^{\circ} \mathrm{C}$ within 30 min to obtain a beam of 3-5 V on the secondary electron multiplier operated at an amplification of 25 relative to the Farady detector. Three blocks with 12 scans each across the isotope pattern were collected in the peak jumping mode. Data were analyzed for outliers by a Dixon test. Measurements that had an internal SD greater than the target precision of $0.5 \%$ for the ${ }^{57} \mathrm{Fe} /{ }^{56} \mathrm{Fe}$ ratio and $1 \%$ for the ${ }^{58} \mathrm{Fe} /{ }^{56} \mathrm{Fe}$ ratio were discarded, and analysis was repeated. Accuracy of the mass spectrometric measurements was verified earlier by analyzing standards containing known enrichments of ${ }^{57} \mathrm{Fe}$ and ${ }^{58} \mathrm{Fe}(11)$.

The precision of the measurements of incorporation of stable isotopes into red blood cells can be estimated based on the uncertainties of the determination of the isotope ratios of both baseline and enriched samples (11, 20). At low fractional Fe incorporation, when the measured isotope ratios are close to the detection limit, the errors increase. The $\mathrm{CV}$ for the lowest ${ }^{57} \mathrm{Fe}$ incorporation found in this study (2.8\%) is 50\%. Similarly, a CV of $25 \%$ can be calculated for the lowest ${ }^{58} \mathrm{Fe}$ incorporation (1.5\%). At higher incorporation values, the $\mathrm{CV}$ will decrease. For example, for the highest measured values of 24.3 and $23.2 \%$ incorporation for ${ }^{57} \mathrm{Fe}$ and ${ }^{58} \mathrm{Fe}$, respectively, the estimated CV is $2 \%$.

Calculation of Fe incorporation into red blood cells. The quantity of administered ${ }^{58} \mathrm{Fe}$ and ${ }^{57} \mathrm{Fe}$ incorporated into red blood cells was calculated in a manner similar to that used by Fomon et al. (20). Circulating Fe was calculated based on body weight and on the assumption of $65 \mathrm{~mL} / \mathrm{kg}$ body weight (20). Furthermore, $90 \%$ of initially absorbed $\mathrm{Fe}$ was assumed to be incorporated into red blood cells (12).

The calculations were somewhat complicated by the fact that the ${ }^{58} \mathrm{Fe}$ label contained a small amount of ${ }^{57} \mathrm{Fe}$, and vice versa. The calculation of ${ }^{57} \mathrm{Fe}$ incorporation into red blood cells was done assuming that the contribution of ${ }^{57} \mathrm{Fe}$ from the ${ }^{58} \mathrm{Fe}$ label was negligible. The amount of ${ }^{58} \mathrm{Fe}$ ingested with the ${ }^{57} \mathrm{Fe}$ label that was incorporated into red blood cells was then calculated, assuming an identical bioavailability for both isotopes present in the ${ }^{57} \mathrm{Fe}$ label (11).

Statistics. Paired $t$ tests were used for comparisons between fractional $\mathrm{Fe}$ incorporation into red blood cells from the two test meals fed in each study. Values were converted to logarithms before statistical analysis and reconverted to antilogarithms to recover the original units (21). Fractional incorporation of each isotope is given the geometric mean $( \pm 1 \mathrm{SD})$. The correlation between $\mathrm{Fe}$ incorporation into red blood cells and age as well as Fe status indices ( $\mathrm{Hb}$ and ferritin) was evaluated by Spearman's rank correlation.

\section{RESULTS}

The contents of protein, $\mathrm{Fe}$, calcium, ascorbic acid, and phytic acid in the four infant formulas as fed are given in Table 1. The concentration of $\mathrm{Fe}$ in the formulas varied between 280 and $300 \mu \mathrm{mol} / \mathrm{L}(15.7$ and $16.8 \mathrm{mg} / \mathrm{L}$ ) among the separate studies. Ascorbic acid was added to a final concentration of $624 \mu \mathrm{mol} / \mathrm{L}(110 \mathrm{mg} / \mathrm{L}$; studies 1 and 2) or 624 and $1249 \mu \mathrm{mol} / \mathrm{L}$ (110 and $220 \mathrm{mg} / \mathrm{L}$; study 3). Analysis of ascorbic acid in study 3 demonstrated mean ratios (analyzed/anticipated values) of $1.01 \pm 0.15$ (mean $\pm \mathrm{SD})$ for the reference bottles $(n=16)$ and 1.09 \pm 0.26 for the parallel bottles $(n=39)$, indicating that the desired amount of ascorbic acid had been added to the formulas and that this ascorbic acid remained stable during the feeding and was ingested by the child.

Individual data on infant characteristics and fractional Fe incorporation into red blood cells are given in Tables $2-4$. The Fe status among the infants showed a large variation, with some infants being $\mathrm{Fe}$ deficient or borderline $\mathrm{Fe}$ deficient. These infants were given $\mathrm{Fe}$ supplements after the study.

A statistically significant effect of phytic acid removal was found in studies 1 and 2, with a greater increase of the $\mathrm{Fe}$ incorporation into red blood cells when $100 \%$ phytic acid was removed (study 2) compared with $83 \%$

Table 1. Content of protein, $\mathrm{Fe}$, calcium (Ca), ascorbic acid, and phytic acid in the soy formulas*

\begin{tabular}{cccccc}
\hline & $\begin{array}{c}\text { Protein } \\
(\mathrm{g})\end{array}$ & $\begin{array}{c}\mathrm{Fe} \dagger \\
(\mu \mathrm{mol})\end{array}$ & $\begin{array}{c}\mathrm{Ca} \\
(\mathrm{mmol})\end{array}$ & $\begin{array}{c}\text { Ascorbic } \\
\text { acid }(\mu \mathrm{mol})\end{array}$ & $\begin{array}{c}\text { Phytic acid } \\
(\mu \mathrm{mol})\end{array}$ \\
\hline Study 1 & & & & & \\
$\quad$ Product A & 19.4 & 300 & 10.9 & 624 & 615 \\
$\quad$ Product B & 19.0 & 280 & 10.0 & 624 & 106 \\
$\begin{array}{l}\text { Study 2 } \\
\quad \text { Product C }\end{array}$ & 20.4 & 295 & 10.8 & 624 & 611 \\
$\quad$ Product D & 18.4 & 300 & 10.7 & 624 & $<2$ \\
Study 3 & & & & & \\
$\quad$ Product A & 19.4 & 300 & 10.9 & 624 & 615 \\
Product A & 19.4 & 300 & 10.9 & 1249 & 615 \\
\hline
\end{tabular}

* Values are given per liter of formula as fed.

$\dagger$ Includes $\mathrm{Fe}$ added as ferrous sulfate either enriched with ${ }^{57} \mathrm{Fe}$ or enriched with ${ }^{58} \mathrm{Fe}$, plus $\mathrm{Fe}$ with normal isotopic composition. 
Table 2. Age, Fe status ( $\mathrm{Hb}$ and ferritin), and fractional $\mathrm{Fe}$ incorporation into red blood cells of infants fed soy formulas with the native (product A) or $83 \%$ reduced content of phytic acid (p.a.) (product B) in study 1

\begin{tabular}{|c|c|c|c|c|c|}
\hline \multirow[b]{2}{*}{ Infant } & \multirow[b]{2}{*}{$\begin{array}{l}\text { Age } \\
\text { (wk) }\end{array}$} & \multirow[b]{2}{*}{$\begin{array}{c}\mathrm{Hb} \\
(\mathrm{g} / \mathrm{L})\end{array}$} & \multirow[b]{2}{*}{$\begin{array}{c}\text { Ferritin } \\
(\mu \mathrm{g} / \mathrm{L})\end{array}$} & \multicolumn{2}{|c|}{$\mathrm{Fe}$ incorporation $(\%)$} \\
\hline & & & & $\begin{array}{c}\text { Product A } \\
\text { native p.a. } \\
\quad\left({ }^{57} \mathrm{Fe}\right)\end{array}$ & $\begin{array}{c}\text { Product B } \\
\text { reduced p.a. } \\
\quad\left({ }^{58} \mathrm{Fe}\right)\end{array}$ \\
\hline 1 & 22 & 118 & 3.1 & 3.4 & 4.0 \\
\hline 2 & 19 & 119 & 1 & 5.5 & 7.3 \\
\hline 3 & 27 & 112 & 1 & 17.0 & 12.3 \\
\hline 4 & 16 & 92 & 3.1 & 3.4 & 5.3 \\
\hline 5 & 19 & 102 & 63.8 & 2.8 & 3.4 \\
\hline 6 & 28 & 112 & 1 & 4.9 & 6.1 \\
\hline 7 & 26 & 123 & 4.6 & 6.9 & 7.4 \\
\hline 8 & 17 & 113 & 17.4 & 3.3 & 4.5 \\
\hline 9 & 28 & 120 & 1 & 6.5 & 7.3 \\
\hline 10 & 30 & 115 & 1 & 12.2 & 23.2 \\
\hline Mean* & 23 & 112 & 2.9 & 5.5 & 6.8 \\
\hline$+1 \mathrm{SD}$ & & & & 10.0 & 12.1 \\
\hline$-1 \mathrm{SD}$ & & & & 3.0 & 3.9 \\
\hline
\end{tabular}

* Arithmetic mean for age and $\mathrm{Hb}$; geometric mean for all others.

dephytinized soy formula (study 1). The geometric mean fractional incorporation increased from 5.5 to $6.8 \%(p<$ 0.05 ; study 1$)$ and from 3.9 to $8.7 \%(p<0.001$; study 2$)$. Increasing the $\mathrm{Fe}$ :ascorbic acid molar ratio from 1:2.1 to $1: 4.2$ in formula containing the native level of phytic acid increased mean $\mathrm{Fe}$ incorporation significantly $(p<0.05)$ from 5.9 to $9.6 \%$ (study 3 ). All children increased their $\mathrm{Fe}$ incorporation into red blood cells when fed the completely dephytinized product compared with the product with its native phytate content (study 2). Similarly, all children had a higher $\mathrm{Fe}$ incorporation from soy formula containing $1249 \mu \mathrm{mol} / \mathrm{L}(220 \mathrm{mg} / \mathrm{L})$ ascorbic acid than from soy formula containing $624 \mu \mathrm{mol} / \mathrm{L}(110 \mathrm{mg} / \mathrm{L}$; study 3).

Correlations between fractional $\mathrm{Fe}$ incorporation into red blood cells and $\mathrm{Fe}$ status $(\mathrm{Hb}$, ferritin) and age were

Table 3. Age, $\mathrm{Fe}$ status ( $\mathrm{Hb}$ and ferritin), and fractional $\mathrm{Fe}$ incorporation into red blood cells of infants fed soy formulas with the native (product C) or 100\% reduced content of phytic acid (p.a.) (product B) in study 2

\begin{tabular}{|c|c|c|c|c|c|}
\hline \multirow[b]{2}{*}{ Infant } & \multirow[b]{2}{*}{$\begin{array}{l}\text { Age } \\
\text { (wk) }\end{array}$} & \multirow[b]{2}{*}{$\begin{array}{c}\mathrm{Hb} \\
(\mathrm{g} / \mathrm{L})\end{array}$} & \multirow[b]{2}{*}{$\begin{array}{c}\text { Ferritin } \\
(\mu \mathrm{g} / \mathrm{L})\end{array}$} & \multicolumn{2}{|c|}{$\mathrm{Fe}$ incorporation (\%) } \\
\hline & & & & $\begin{array}{c}\text { Product } C \\
\text { native p.a. } \\
\left({ }^{58} \mathrm{Fe}\right)\end{array}$ & $\begin{array}{c}\text { Product D } \\
\text { reduced p.a. } \\
\left({ }^{57} \mathrm{Fe}\right) \\
\end{array}$ \\
\hline 1 & 24 & 123 & 8 & 2.3 & 8.9 \\
\hline 2 & 19 & 122 & 1 & 3.9 & 7.2 \\
\hline 3 & 16 & 122 & 6.8 & 9.8 & 24.2 \\
\hline 4 & 13 & 92 & 19.2 & 1.5 & 3.5 \\
\hline 5 & 25 & 117 & 1 & 15.2 & 17.2 \\
\hline 6 & 17 & 118 & 1 & 2.2 & 9.7 \\
\hline 7 & 18 & 121 & 2 & 11.4 & 19.3 \\
\hline 8 & 13 & 113 & 15.5 & 3.6 & 4.5 \\
\hline 9 & 17 & 101 & 1 & 2.8 & 7.1 \\
\hline 10 & 18 & 116 & 8.5 & 1.7 & 4.4 \\
\hline Mean* & 18 & 114 & 3.5 & 3.9 & 8.7 \\
\hline$+1 \mathrm{SD}$ & & & & 9.0 & 16.9 \\
\hline$-1 S D$ & & & & 1.7 & 4.5 \\
\hline
\end{tabular}

* Arithmetic mean for age and $\mathrm{Hb}$; geometric mean for all others.
Table 4. Age, Fe status ( $\mathrm{Hb}$ and ferritin), and fractional $\mathrm{Fe}$ incorporation into red blood cells of infants fed soy formula (product A) containing its native level of phytic acid and either $624 \mu \mathrm{mol} / \mathrm{L}(110 \mathrm{mg} / \mathrm{L})$ or $1249 \mu \mathrm{mol} / \mathrm{L}(220 \mathrm{mg} / \mathrm{L})$ ascorbic acid (a.a.) in study 3

\begin{tabular}{|c|c|c|c|c|c|}
\hline \multirow[b]{2}{*}{ Infant } & \multirow[b]{2}{*}{$\begin{array}{l}\text { Age } \\
\text { (wk) }\end{array}$} & \multirow[b]{2}{*}{$\begin{array}{c}\mathrm{Hb} \\
(\mathrm{g} / \mathrm{L})\end{array}$} & \multirow[b]{2}{*}{$\begin{array}{c}\text { Ferritin } \\
(\mu \mathrm{g} / \mathrm{L})\end{array}$} & \multicolumn{2}{|c|}{$\mathrm{Fe}$ incorporation (\%) } \\
\hline & & & & $\begin{array}{c}\text { Product A } \\
624 \mu \mathrm{mol} \mathrm{a} \text {.a. } / \mathrm{L} \\
\left({ }^{58} \mathrm{Fe}\right)\end{array}$ & $\begin{array}{c}\text { Product A } \\
1249 \mu \mathrm{mol} \text { a.a. } / \mathrm{L} \\
\left({ }^{57} \mathrm{Fe}\right)\end{array}$ \\
\hline 1 & 22 & 110 & 29.2 & 6.6 & 10.2 \\
\hline 2 & 25 & 114 & 39.1 & 5.9 & 8.2 \\
\hline 3 & 26 & 106 & 24.4 & 4.3 & 7.0 \\
\hline 4 & 29 & 118 & 8.1 & 8.5 & 24.3 \\
\hline 5 & 21 & 113 & 39.9 & 10.7 & 21.3 \\
\hline 6 & 25 & 107 & 8.5 & 5.4 & 6.8 \\
\hline 7 & 20 & 114 & 104 & 2.9 & 7.4 \\
\hline 8 & 16 & 112 & 98.4 & 6.1 & 7.3 \\
\hline 9 & 17 & 113 & 14.1 & 4.0 & 8.1 \\
\hline 10 & 16 & 121 & 42.3 & 6.4 & 6.5 \\
\hline Mean* & 22 & 113 & 29.3 & 5.7 & 9.5 \\
\hline$+1 \mathrm{SD}$ & & & & 8.3 & 15.3 \\
\hline$-1 \mathrm{SD}$ & & & & 3.9 & 5.8 \\
\hline
\end{tabular}

calculated for each individual test meal as well as for data collected from all infants fed soy formulas containing the native level of phytic acid. A statistically significant inverse correlation $(p<0.05)$ was found between serum ferritin and $\mathrm{Fe}$ incorporation for each of the two test meals in study 1 (A and B), but not for any other test meals. $\mathrm{Hb}$ was found to be significantly correlated to fractional $\mathrm{Fe}$ incorporation into red blood cells only for one test meal (study 2; D). Furthermore, only Fe incorporation measured from test meal $\mathrm{A}$ was found to be correlated with age $(p<0.05)$. When data on Fe status indices (ferritin and $\mathrm{Hb}$ ) as well as age for all infants in studies 1-3 were correlated with $\mathrm{Fe}$ incorporation from the formulas containing the native level of phytic acid, only age was found to be significantly related to fractional $\mathrm{Fe}$ incorporation into red blood cells $(p<0.05)$.

\section{DISCUSSION}

After exhausting the placentally transferred $\mathrm{Fe}$, infants depend on dietary Fe for their rapidly expanding blood volume and replacement of $\mathrm{Fe}$ losses (22). It is important therefore to ensure an adequate $\mathrm{Fe}$ supply in the diet consumed during early life. With infant foods based on soy protein, this is of special concern, because soy protein isolates contain phytic acid, which is a potent inhibitor of $\mathrm{Fe}$ absorption. In this study, we have compared two approaches for optimizing Fe bioavailability from soy formula: either degrading the phytic acid or adding ascorbic acid as an enhancer of $\mathrm{Fe}$ absorption. We have shown that both completely degrading the phytic acid and increasing the ascorbic acid content from its normal level of $624 \mu \mathrm{mol} / \mathrm{L}(110 \mathrm{mg} / \mathrm{L})$ to $1249 \mu \mathrm{mol} / \mathrm{L}(220 \mathrm{mg} / \mathrm{L})$ can approximately double the fractional incorporation of $\mathrm{Fe}$ into red blood cells in infants consuming soy formula.

This is the first report that degradation of phytic acid in infant foods increases Fe bioavailability to infants. From 
our study, it would appear that most, if not all, of the phytic acid should be degraded to ensure a meaningful increase in $\mathrm{Fe}$ incorporation into red blood cells. In study 1 (Table 2), 83\% degradation of phytic acid increased fractional $\mathrm{Fe}$ incorporation from 5.5 to $6.8 \%$, whereas complete degradation increased these values from 3.9 to $8.7 \%$ (study 2, Table 3).

Earlier studies in adults fed a liquid soy meal based on soy protein isolate similarly reported an increased $\mathrm{Fe}$ bioavailability when phytic acid was removed from the isolate (8). In this adult study, even very small amounts of residual phytic acid were reported to be strongly inhibitory, and phytic acid had to be $98 \%$ degraded before a meaningful increase in $\mathrm{Fe}$ absorption was observed. Soy-based formulas, however, contain far less soy protein isolate $(18-20 \mathrm{~g} / \mathrm{L}$, Table 1$)$ than the $\sim 90 \mathrm{~g} / \mathrm{L}$ used in the adult studies $(8)$, and a $83 \%$ reduction in phytic acid was sufficient to give a small but significant $(p<0.05)$ increase in fractional $\mathrm{Fe}$ incorporation into red blood cells in infants. Both the present study and that of Hurrell et al. (8) would support the conclusion that a meaningful increase in $\mathrm{Fe}$ bioavailability in soy-based meals can be obtained by decreasing the phytic acid:Fe molar ratio to 0.40 and below but that to optimize $\mathrm{Fe}$ bioavailability phytic acid should be completely removed. Even after complete removal of phytic acid, however, the soy protein itself still inhibits $\mathrm{Fe}$ absorption (23).

As well as increasing $\mathrm{Fe}$ bioavailability, phytic acid removal from soy formulas could also potentially increase zinc absorption and retention. Zinc absorption was increased significantly when $90 \%$ dephytinized soy formula was compared with conventional soy formula in infant rhesus monkeys and in rat pups (24). However, when $60 \%$ dephytinized soy formula was fed to infants, there was no improvement in zinc absorption, although there was a significant reduction in the fecal excretion of endogenous zinc (25). In adult subjects, phytic acid reduction in wheat bread has also been shown to improve zinc absorption (26).

The enhancing effect of ascorbic acid on Fe bioavailability from both milk-based and soy-based formulas is well known. The enhancing effect is more pronounced in milk formulas than in soy formulas presumably because of the phytic acid present in the soy protein isolate. The effect of ascorbic acid on Fe absorption from milk-based formulas has been studied in both infants and adults. In infants consuming formulas containing $\mathrm{Fe}$ 179-340 $\mu \mathrm{mol} / \mathrm{L}(10-19 \mathrm{mg} / \mathrm{L})$, Stekel et al. (27) demonstrated that maximum $\mathrm{Fe}$ absorption was obtained with a molar ratio of Fe:ascorbic acid of 1:4. A plateau was reached thereafter, and no further increase in $\mathrm{Fe}$ absorption could be observed by increasing the ascorbic acid content. In adult women consuming milk-based infant formula, Fe absorption increased 5-fold when the Fe:ascorbic acid ratio was $1: 2$ compared with no ascorbic acid and more than 10 -fold when the ratio was 1:6 (2). The same workers showed that ascorbic acid had a less marked effect on Fe absorption from soy formula. Fe absorption by adult women increased only 2- to 3-fold with an Fe:ascorbic acid ratio of 1:6. Gillooly et al. (1) had earlier shown that a molar ratio of 1:4 is necessary to improve Fe absorption from soy formula in adults with no further significant increase in absorption if the ratio is increased to 1:8. The results of our present study in infants are consistent with the findings in adults and indicate that a 2 -fold increase in fractional $\mathrm{Fe}$ incorporation into red blood cells is obtained when the molar ratio of Fe:ascorbic acid is increased from $1: 2.1$ to $1: 4.2$. Whether additional ascorbic acid would further increase Fe bioavailability is not known.

The necessity to further improve $\mathrm{Fe}$ bioavailability from the presently commercialized soy formulas could be questioned by the finding that soy formulas are as efficient as milk-based formulas in preventing Fe deficiency in infants up to 9 mo of age (28), even though the $\mathrm{Fe}$ absorption from the soy formulas used in the study was reported to be only $1.7 \%$ in adult women. Results from a previous study made in infants would indicate that $\mathrm{Fe}$ absorption from commercial soy formulas is of the same magnitude as that from milk-based formulas. In the study of Rios et al. (12), mean Fe absorption from $120 \mathrm{~mL}$ of formula containing Fe 215-394 $\mu \mathrm{mol} / \mathrm{L}(12-22 \mathrm{mg} / \mathrm{L}$, labeled with ${ }^{59} \mathrm{Fe}$ ) was $5.4 \%$ (range $1.0-21.9 \%$ ) from soy formulas compared with 3.9 and $3.4 \%$ (range $0.7-23 \%$ ) from milk formulas. No information was given on the content of ascorbic acid in the formulas. It should be noted that milk-based formulas also contain inhibitors of Fe absorption, i.e. bovine casein (29) and calcium (30). In the present study, the mean fractional $\mathrm{Fe}$ incorporation into red blood cells from soy formula (Fe $300 \mu \mathrm{mol} / \mathrm{L}$ ) containing its native level of phytic acid and ascorbic acid $624 \mu \mathrm{mol} / \mathrm{L}$ was $5.5 \%$ in study 1 and $3.9 \%$ in study 2 . Using the same study design, we reported earlier that fractional $\mathrm{Fe}$ incorporation into red blood cells by infants from a whey-predominant milk-based formula containing $\mathrm{Fe} 12 \mathrm{mg} / \mathrm{L}$ and ascorbic acid $80 \mathrm{mg} / \mathrm{L}$ was 6.7 and $6.6 \%$ (11). Despite the relatively low $\mathrm{Fe}$ bioavailability from both soy formulas and milk-based formulas, their relatively high $\mathrm{Fe}$ content normally ensures that sufficient $\mathrm{Fe}$ is provided to meet the Fe requirements of the child. A recent study reported that breast milk contains only 1.8 $3.6 \mu \mathrm{mol} \mathrm{Fe} / \mathrm{L}(0.1-0.2 \mathrm{mg} / \mathrm{L})(31)$, so that an infant formula with $\mathrm{Fe} 215 \mu \mathrm{mol} / \mathrm{L}(12 \mathrm{mg} / \mathrm{L})$ would contain at least 60 times more Fe. It is not known to what extent infants can regulate their $\mathrm{Fe}$ absorption depending on $\mathrm{Fe}$ status. No conclusive data on the correlation between $\mathrm{Fe}$ status and fractional $\mathrm{Fe}$ incorporation into red blood cells were found in the present study. However, a significant correlation between age and fractional $\mathrm{Fe}$ incorporation from the soy formulas containing the native content of phytic acid was observed when data from all infants were included. A significant inverse correlation between serum ferritin and circulating ${ }^{58} \mathrm{Fe}$ was reported earlier by Fomon et al. (20).

In conclusion, we have shown that fractional $\mathrm{Fe}$ incorporation into red blood cells by infants fed soy formula can be increased by phytic acid reduction or by ascorbic 
acid addition. Phytic acid reduction, but not the addition of ascorbic acid, would also probably increase zinc bioavailability. The addition of phytase to infant foods, however, still has to be approved by the legislative authorities. Based on these findings, and with the possibility of varying the amount of Fe fortification, formula manufacturers have the choice of several alternative strategies to ensure optimum $\mathrm{Fe}$ nutrition in infants consuming soy formula.

\section{REFERENCES}

1. Gillooly M, Torrance JD, Bothwell TH, MacPhail AP, Mills W, Mayet F 1984 The relative effect of ascorbic acid on iron absorption from soy-based and milk-based infant formulas. Am J Clin Nutr 40:522-527

2. Derman DP, Ballot D, Bothwell TH, MacFarlane BJ, Baynes RD, MacPhai AP, Gillooly M, Bothwell JE, Bezwoda WR 1987 Factors influencing the absorption of iron from soya-bean protein products. Br J Nutr 57:345-353

3. Sandström B, Cederblad A, Lönnerdal B 1983 Zinc absorption from human milk, cow's milk, and infant formulas. Am J Dis Child 137:726-729

4. Golden BE, Golden MHN 1981 Plasma zinc, rate of weight gain, and the energy cost of tissue deposition in children recovering from severe malnutrition on a cow's milk or soya protein based diet. Am J Clin Nutr 34:892-899

5. Steichen JJ, Tsang RC 1987 Bone mineralization and growth in term infants fed soy-based or cow milk-based formula. J Pediatr 110:687-692

6. Venkataraman PS, Luhar H, Neylan MJ 1992 Bone mineral metabolism in full-term infants fed human milk, cow milk-based, and soy-based formulas. Am J Dis Child 146:1302-1305

7. Hallberg L, Brune M, Rossander L 1989 Iron absorption in man: ascorbic acid and dose-dependent inhibition by phytate. Am J Clin Nutr 49:140-144

8. Hurrell RF, Juillerat M-A, Reddy MB, Lynch SR, Dassenko SA, Cook JD 1992 Soy protein, phytate, and iron absorption in humans. Am J Clin Nut $56: 573-578$

9. Brune M, Rossander-Hultén L, Hallberg L, Gleerup A, Sandberg A-S 1992 Iron absorption from bread in humans: inhibiting effects of cereal fiber phytate and inositol phosphates with different numbers of phosphate groups. J Nutr 122:442-449

10. Siegenberg D, Baynes RD, Bothwell TH, Macfarlane BJ, Lamparelli RD, Car NG, MacPhail P, Schmidt U, Tal A, Mayet F 1991 Ascorbic acid prevents the dose-dependent inhibitory effects of polyphenols and phytates on nonhemeiron absorption. Am J Clin Nutr 53:537-541

11. Kastenmayer P, Davidsson L, Galan P, Cherouvrier F, Hercberg S, Hurrell RF 1994 A double stable isotope technique for measuring iron absorption in infants. Br J Nutr 71:411-424

12. Rios E, Hunter RE, Cook JD, Smith NJ, Finch CA 1975 The absorption of ron as supplements in infant cereal and infant formulas. Pediatrics 55:686-693

13. Makover RU 1970 Extraction and determination of phytic acid in beans. Cereal Chem 47:288-296
14. Anonymous 1990 AOAC Method 967:21. In: Hilrich K (ed) Official Methods of Analysis of the AOAC. AOAC International, Arlington, VA, pp 1058-1059

15. Harris LJ, Mapson LW, Wang YL 1992 Vitamin methods. A simple potentiometric method for determining ascorbic acid, suitable for use with coloured extracts. Biochem J 36:183-195

16. Anonymous 1985 Serum ferritin. In: Cook JD, Bothwell TH, Covell AM, Dallman PR, Lynch SR, Worwood MA (contributors) Measurements of Iron Status. A Report of the International Nutritional Consultative Group. The Nutrition Foundation, Washington, DC, pp 35-54

17. Fasset JD, Powell LJ, Moore LJ 1984 Determination of iron in serum and water by resonance ionisation isotope dilution mass spectrometry. Anal Chem 56:2228-2233

18. Götz A, Heumann KG 1987 Heavy metal trace determination with a compact thermal ionisation quadruple mass spectrometer. Part 2. Analysis of food samples. Fresenius Z Anal Chem 326:118-122

19. Beer B, Heumann KG 1992 Trace analysis of $U$, Th and other heavy metals in high purity aluminium with isotope dilution mass spectrometry. Fresenius $Z$ Anal Chem 343:741-745

20. Fomon SJ, Janghorbani M, Ting BTG, Ziegler EE, Rogers RR, Nelson SE, Ostegaard LS, Edwards BB 1988 Erythrocyte incorporation of ingested 58-iron by infants. Pediatr Res 24:20-24

21. Cook JD, Layrisse M, Finch CA 1969 The measurement of iron absorption. Blood 33:421-429

22. Dallman PR 1992 Changing iron needs from birth through adolescence. In: Fomon SJ, Zlotkin S (eds) Nutritional Anemias. Nestlé Nutrition Workshop Series. Raven Press, New York, pp 29-36

23. Lynch SR, Dassenko SA, Cook JD, Juillerat M-A, Hurrell RF 1994 Effect of the protein component of soybean protein isolates on iron absorption in humans. Am J Clin Nutr (in press)

24. Lönnerdal B, Bell JG, Hendrickx AG, Burns RA, Keen CL 1988 Effect of phytate removal on zinc absorption from soy formula. Am $\mathrm{J}$ Clin Nutr 48:1301-1306

25. Ziegler EE, Janghorbani M, Nelson SE, Edwards BB 1990 Effect of phytate reduction on mineral absorption from soy-based infant formula. Am J Clin Nutr 51:528(abstr)

26. Nävert B, Sandström B, Cederblad A 1985 Reduction of the phytate content of bran by leavening in bread and its effect on absorption of zinc in man. $\mathrm{Br}$ J Nutr 53:47-53

27. Stekel A, Olivares M, Pizarro F, Chadud P, Lopez I, Amar M 1986 Absorption of fortification iron from milk formulas in infants. Am $\mathbf{J}$ Clin Nut 43:917-922

28. Hertrampf E, Cayazzo M, Pizarro F, Stekel A 1986 Bioavailability of iron in soy-based formula and its effect on iron nutriture in infancy. Pediatrics $78: 640-645$

29. Hurrell RF, Lynch SR, Trinidad TP, Dassenko SA, Cook JD 1989 Iron absorption in humans as influenced by bovine milk proteins. Am J Clin Nutr 49:546-552

30. Hallberg L, Rossander-Hulthén L, Brune M, Gleerup A 1992 Bioavailability in man of iron in human milk and cow's milk in relation to their calcium contents. Pediatr Res 31:524-527

31. Davidsson L, Kastenmayer P, Yuen M, Lönnerdal B, Hurrell RF 1993 Influence of lactoferrin on iron absorption from human milk in infants. Pediatr Res 35:117-124 